\title{
Synthesis, Characterization, and Crystal Structures of Novel Coordination Polymers of Praseodymium(III) and Neodymium(III) Containing Dialkyl Phosphate
}

\author{
Masoud Rafizadeh, Vahid Amani, $\stackrel{* *}{*}$ and Neda S. Mortazavi \\ Factlty of Chemistry, Tarbiat Hoallem Universitw, Tehran, Iran \\ ${ }^{\dagger}$ Islamic Azad thiversity. Shahr-e-Rev Branch. Tehran, Iran. ${ }^{*}$ E-mail: v amani2002 ôvahoocom \\ Recened November 13, 2008, Accepted December 15, 2008
}

\begin{abstract}
Key Words: Neodỵmium(III). Praseodỵmium(III). Diethyl phosphate. Dimethỵl phosphate. Dimethỵl
\end{abstract} sulfoxide

Metal complexes incorporating various types of phosphate moieties are being examined in order to explore the metalbinding properties of such ligands and to elucidate the importance of these interactions in biological systems. Mononuclear, ${ }^{1-3}$ binuclear. $^{2-16}$ trinuclear. $^{1: 18}$ tetranuclear $^{19-23}$ and polymeric ${ }^{-4}$ complexes have been reported in which the phosphate moieties adopt monodentate. chelating. and bridging binding modes. These examples include heterometallic complexes. ${ }^{25}$ Moreover. in addition to phosphate and phosphate ester complexes: complexes incorporating nucleic acid fragments. ATP. polyphosphates, and polyphosphate esters have been structurally characterized. ${ }^{-6-25}$ Recently. we have reported the synthesis and crystal structure of $\left[\mathrm{La}(\mu-\mathrm{DMP})_{2}\left(\mu-\mathrm{NO}_{3}\right)(\mathrm{DMSO})\right]_{17 \cdot}{ }^{30}$

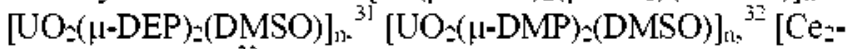
$\left.(\mu-\mathrm{DEP})_{6}(\mathrm{TEP})\right]_{3 *}{ }^{{ }_{3}}\left\{\left[\mathrm{Mn}(\mu-\mathrm{DMP})_{3}(\mu-\mathrm{DMSO})_{2}(\mathrm{DMSO})\left(\mathrm{H}_{2} \mathrm{O}\right)\right]-\right.$ $\mathrm{NO}_{3} \cdot \mathrm{H}_{2} \mathrm{O}_{31)}^{{ }^{34}}\left[\mathrm{Cu}_{-}(\mu-\mathrm{DMP})_{4}(\mu-\mathrm{DMSO})\right]_{11}{ }^{35}$ and $\left[\mathrm{Mn}-\left(\mu_{3}-\mathrm{DMP}\right)=\right.$ $\left.-(\mu-\mathrm{DMP})_{2}\right]_{17 .}$. phosphate. TEP is triethyl phosphate and DMSO is dimethyl sulfoxide). In these complexes. DMP and DEP act as an $\mathrm{O}$-atom donor ligand forming coordination polymers in the solid state. Also, we reported the synthesis and crystal structures of $\left[\mathrm{Ni}\left(\mathrm{H}_{2} \mathrm{O}\right)_{6}\right](\mathrm{DMP})_{2}$ as an ionic complex. "In this complex. DMP is not bonded to the metal, and acts as a independent counter-ion. We have also reported the synthesis and crystal structures of $\left[\mathrm{Fe}_{16}\left(\mu_{3}-\mathrm{O}\right)_{8}\left(\mu_{3}-\mathrm{OH}\right)_{4}(\mu-\mathrm{OH})_{4}(\mu-\mathrm{DMP})_{12}(\mu-\mathrm{OAC})_{]_{2}-}\right.$ $\left.(\mathrm{DMSO})_{4}\right] \cdot 2 \mathrm{DMSO} \cdot 1.5 \mathrm{H}_{2} \mathrm{O} .^{38}$ within which an macromolecule constellation consisting of sixteen iron ion connected by twelve bridging dimethyl phosphate. twelve bridging acetate, eight $\mu_{3}$-oxo. four $\mu_{3}-\mathrm{OH}$. four $\mu-\mathrm{OH}$ and four dimethyl sulfoxide ligands. We now report on the synthesis. characterization and crystal structure of novel polymer of praseodymium(III) and neodymium(III) complexes.

\section{Experimental Section}

All chemicals were purchased from Merck and Aldrich. Infrared spectra $\left(4000-250 \mathrm{~cm}^{-1}\right)$ of solid samples were taken as $1 \%$ dispersion in $\mathrm{KBr}$ pellets using a Shimadzu-470 spectrometer. ${ }^{1} \mathrm{H}$ NMR, ${ }^{13} \mathrm{C}$ NMR and ${ }^{31} \mathrm{P}$ NMR spectra were acquired on a Bruker AC $-300 \mathrm{MHz}$ spectrometer at ambient temperature in $\mathrm{D}_{2} \mathrm{O}$. Melting points were is uncorrected and were obtained by a Kofler Heizbank Rechart type $78+1$ melting point apparatus

Synthesis of $\left[\mathrm{Nd}(\mu-\mathrm{DEP})_{3}\right]_{\mathbf{n}}(\mathbf{1})$. Triethyl phosphate (3.3 lg. $3.1 \mathrm{~mL}, 18 \mathrm{mmol})$ was added to a solution of $\mathrm{NdCl}_{3}(0.93 \mathrm{~g}$, $3.6 \mathrm{mmol})$ in ethanol $(40 \mathrm{~mL})$ and DMSO $(5 \mathrm{~mL})$ and the resulting pale violet solution was stirred at $40^{\circ} \mathrm{C}$ for 30 minute. Then. it was left to evaporate slowly at roon temperature. After two months. colorless prismatic crystals of 1 were isolated (yield 1.62 g. $74.56 \%$, nl.p $<300^{\circ} \mathrm{C}$ ). IR $\left(\mathrm{KBr} . \mathrm{cm}^{.1}\right)$ : 2984s. 2940m. 2912m (vCH), 1446w. 1399m. 1372w, 1197s. $1181 \mathrm{~s} .1168 \mathrm{~s} .1117 \mathrm{~s} .1093 \mathrm{~s} .1066 \mathrm{~s} .1044 \mathrm{~s}$ (vC-O-P). 977s. 825 s. $778 \mathrm{~m}$ (v-P-O). $576 \mathrm{~m} .541 \mathrm{~m} .504 \mathrm{ml} .409 \mathrm{w} .388 \mathrm{~m} .332 \mathrm{w}$ (vNd-O). ${ }^{1} \mathrm{H}$ NMR (D-O): 1.52 (bs. $\mathrm{CH}_{3}-\mathrm{CH}_{2}$ ) and 4.71 (bs. $\left.\mathrm{CH}_{3}-\mathrm{CH}_{2}\right)$ ppm. ${ }^{12} \mathrm{C}$ NMR $\left(\mathrm{D}_{2} \mathrm{O}\right): 1 \overline{6.0}\left(\mathrm{~d} . \mathrm{J}_{i p}=6.3 \mathrm{~Hz}\right)$ and $63.3\left(\mathrm{~d} . \mathrm{J}_{c p}=4.6 \mathrm{~Hz}\right) \mathrm{ppm}$. ${ }^{31} \mathrm{P}$ NMR $\left(\mathrm{D}_{2} \mathrm{O}\right): 40.2$ (s) ppm. Elemental analysis (\%) calcd. for $\mathrm{C}_{12} \mathrm{H}_{301} \mathrm{NdO}_{12} \mathrm{P}_{3}(603.5 \mathrm{lg} /$ mol): C. 23.86: H, 4.97. Found. C. 23.71; H, 4.89.

Synthesis of $\left[\mathrm{Pr}(\mu-\mathrm{DMP})_{2}\left(\mu-\mathrm{NO}_{3}\right)(\mathrm{DMSO})\right]_{n}(2)$. Trimethỵl phosphate $(2.55 \mathrm{~g} .2 .1 \mathrm{~mL}, 18 \mathrm{mmol})$ was added to a solution of $\operatorname{Pr}\left(\mathrm{NO}_{3}\right)_{3} \cdot 5 \mathrm{H}_{2} \mathrm{O}(1.53 \mathrm{~g} .3 .6 \mathrm{mmol})$ in ethanol $(40 \mathrm{~mL})$ and DMSO $(5 \mathrm{~mL})$ and the resulting pale green solution was stirred at $40^{\circ} \mathrm{C}$ for 30 minute. Then it was left to evaporate slowly at room temperature. After three months, pale green needle crystals of 2 were isolated (yield 1.48 g. $77.40 \%, \mathrm{~m} . \mathrm{p}<300^{\circ} \mathrm{C}$ ). IR $\left(\mathrm{KBr}, \mathrm{cm}^{-1}\right)$ : 3013s. 2992s. 2964s, 2933m, 2860s (vCH), 1482s. $1465 \mathrm{~s}, 14+3 \mathrm{~s}, 1406 \mathrm{~s}, 1361 \mathrm{~s}, 1340 \mathrm{~s}, 1311 \mathrm{~s}, 1243 \mathrm{~s}, 1160 \mathrm{~s}, 1136 \mathrm{~s}$. $108 \mathrm{ls} .1020 \mathrm{~s}(\mathrm{vC}-\mathrm{O}-\mathrm{P}) .995 \mathrm{~s}$. $v(\mathrm{~S}=\mathrm{O}) .965 \mathrm{~s} .946 \mathrm{~s} .849 \mathrm{~s} .838 \mathrm{~s}(\mathrm{v}$ P-O). $820 \mathrm{~s} .785 \mathrm{~s} .778 \mathrm{~s} .755 \mathrm{~s} .730 \mathrm{~mL}, 683 \mathrm{w}, 604 \mathrm{~m} .576 \mathrm{~m} .534 \mathrm{~s}$, $490 \mathrm{~s}, 412 \mathrm{~s}$. $402 \mathrm{~s}, 368 \mathrm{ml}, 323 \mathrm{w}$ (vPr-O-P) and (vPr-O-S). $286 \mathrm{~m}$ $(v \mathrm{Pr}-\mathrm{O}-\mathrm{N}) \cdot{ }^{\mathrm{j}} \mathrm{H} \mathrm{NMR}\left(\mathrm{D}_{2} \mathrm{O}\right): 2.88\left(\mathrm{~s} . \mathrm{CH}_{3}\right)$ and $5.69\left(\mathrm{~d}_{\mathrm{H}}=\right.$ $10.5 \mathrm{~Hz}$. OMe) ppm. ${ }^{13} \mathrm{CNMR}\left(\mathrm{D}_{2} \mathrm{O}\right): 38.9\left(\mathrm{~s}, \mathrm{CH}_{3}\right)$ and $55.7(\mathrm{~s}$, $\left.\mathrm{OCH}_{2}\right) \mathrm{ppm} .{ }^{31} \mathrm{P}$ NMR $\left(\mathrm{D}_{2} \mathrm{O}\right): 41.0$ (s) ppm.

Elemental analysis (\%) calcd. for $\mathrm{C}_{6} \mathrm{H}_{1} \mathrm{NO}_{1} \mathrm{P}_{2} \mathrm{PrS}(531.12 \mathrm{~g} /$ mol): C. $13.55 ; \mathrm{H}, 3.39 ;$ N. 2.64. Found. C. $13.43: \mathrm{H}, 3.31: \mathrm{N}$, 2.56 .

$\mathrm{X}$-ray Stucture Analysis. The X-ray diffraction measurements were made on a Bruker APEX II CCD diffractometer for 1 and Bruker SMART 1000 CCD diffractometer for 2 (Mo-K $\alpha$ radiation. graphite monochromator. $\lambda=0.71073 \AA$ ). The structures of 1 and 2 were solved by SHELXTL ver. 5.1. ${ }^{39}$ The non-lrydrogen atoms were refined anisotropically by a full-matrix least-squares method based on $\mathrm{F}^{2}$ using SHEL XTL ver. 5.1 for 1 and 2.39 


\section{Results and Discussion}

1 can be obtained by the reaction of $\mathrm{NdCl}_{3}$ with TEP in EtOH and DMSO as colorless prismatic crystals according to Equation (1)

$$
\begin{aligned}
& \mathrm{NdCl}_{3}-5 \mathrm{n} \mathrm{OP}\left(\mathrm{OC}_{2} \mathrm{H}_{5}\right)_{3} \frac{\mathrm{EtOH}, \mathrm{DMSO}}{-3 \mathrm{C}_{2} \mathrm{H}_{5} \mathrm{Cl}}- \\
&\left\{\mathrm{Nd}\left[\mu-\mathrm{O}_{2} \mathrm{P}\left(\mathrm{OC}_{2} \mathrm{H}_{5}\right)_{2}\right]_{3}\right\}_{n}
\end{aligned}
$$

2 can be obtained by the reaction of $\operatorname{Pr}\left(\mathrm{NO}_{3}\right)_{3} \cdot 5 \mathrm{H}_{2} \mathrm{O}$ with TEP in EtOH and DMSO as pale green needle crystals according to Equation (2).

$$
\begin{gathered}
\operatorname{Pr}\left(\mathrm{NO}_{3}\right)_{3} \cdot 5 \mathrm{H}_{2} \mathrm{O}+5 \mathrm{n} \mathrm{OP}\left(\mathrm{OCH}_{3}\right)_{3} \frac{\mathrm{EHH}, \mathrm{DMSO}}{-2 \mathrm{nCH} \mathrm{NO}_{3}} \\
\left\{\operatorname{Pr}\left[\mu-\mathrm{O}_{2} \mathrm{P}\left(\mathrm{OCH}_{3}\right)_{2}\right]_{2}\left(\mu-\mathrm{NO}_{3}\right)(\mathrm{DMSO}\}_{11}\right.
\end{gathered}
$$

Both complexes are air-stable. IR spectra of $\mathbf{1}$ and $\mathbf{2}$ show a very sharp absorption peak for the $\mathrm{CH}$ stretching vibrations in the range of $\mathrm{ca} 3013$ to $2860 \mathrm{~cm}^{-1}$. Strong phosphate stretches at 1197 and $1168 \mathrm{~cm}^{-1}$ for 1 and 1243 and $1136 \mathrm{~cm}^{-1}$ for 2 . Five strong sharp bands at $1181.1093 .1066,1054$, and $1044 \mathrm{~cm}^{-1}$ for 1 and 1189.1160 .1036 .1081 and $1020 \mathrm{~cm}^{-1}$ for 2 are due to $\mathrm{C}-\mathrm{O}$ of $\mathrm{P}-\mathrm{O}-\mathrm{C}$ species. Bands at 825 and $778 \mathrm{~cm}^{-1}$ for 1 and 849 and $838 \mathrm{~cm}^{-1}$ for 2 corresponds to $\mathrm{V}(\mathrm{P}-\mathrm{O})$ of $\mathrm{P}-\mathrm{O}-\mathrm{C}$ phosphate ester fragment. $\mathrm{S}=\mathrm{O}$ stretching vibration for complex $\mathbf{2}$ is seen at $995 \mathrm{~cm}^{-1}$. Other $\operatorname{Pr}(\mathrm{III})$ DMSO complexes reported in the literature have shown $v(S=O)$ in the $992-998 \mathrm{~cm}^{-1}$ region. ${ }^{4(i)}$ Several bands in the $576-323 \mathrm{~cm}^{-1}$ spectral region are assigned to the $v(\mathrm{P}-\mathrm{O}-\mathrm{Nd}), v(\mathrm{P}-\mathrm{O}-\mathrm{Pr})$ and $v(\mathrm{~S}=\mathrm{O}-\mathrm{Pr})$ stretching vibrations for complex 1 and 2. acilt $T$ The $\mathrm{Pr}-\mathrm{ONO}_{2}$ stretching vibra-

\begin{tabular}{|c|c|c|}
\hline & Complex 1 & Complex 2 \\
\hline romula & $\mathrm{C}_{12} \mathrm{H}_{30} \mathrm{NdO}_{12} \mathrm{P}_{3}$ & $\mathrm{C}_{6} \mathrm{H}_{18} \mathrm{NO}_{12} \mathrm{P}_{2} \mathrm{PrS}$ \\
\hline Formula weight & 603.51 & 531.12 \\
\hline Temperature /K & $100(2)$ & $120(2)$ \\
\hline Crystal system, Space group & Triclinic, $P_{\overline{1}}$ & Montoclinic, $P 2_{1} / \mathrm{c}$ \\
\hline Crystal sice $/ \mathrm{mm}^{*}$ & $0.22 \times 0.12 \times 0.09$ & $0.55 \times 0.08 \times 0.06$ \\
\hline$a / \AA$ & $10.2503(9)$ & $17.0016(11)$ \\
\hline$b / \AA$ & $11.2599(9)$ & $9.9709(7)$ \\
\hline$C / \AA$ & $20.6739(17)$ & $10.1173(7)$ \\
\hline$\alpha /{ }^{\circ}$ & $100.677(2)$ & 90 \\
\hline$\beta /{ }^{\circ}$ & $90.619(2)$ & $97.0510(10)$ \\
\hline$\gamma^{\circ}$ & $92.06 \mathrm{I}(2)$ & 90 \\
\hline Volume $/ \AA^{3}$ & $2342.9(3)$ & $1702.1(2)$ \\
\hline Z, Density (calc.) $/ \mathrm{g} \mathrm{cm}^{3}$ & $2,1.711$ & $4,2.073$ \\
\hline$\theta$ ranges for data collection & $1.84-27.88$ & $2.37-29.00$ \\
\hline$F(000)$ & 1212 & 1048 \\
\hline Absorption coefticient $\mathrm{mm}^{\mathrm{l}}$ & 2.472 & 3.229 \\
\hline \multirow[t]{3}{*}{ Index ranges } & $-13 \leq h \leq 13$ & $-23 \leq \mathrm{h} \leq 22$ \\
\hline & $-14 \leq k \leq 14$ & $-1 \hat{3} \leq \mathrm{k} \leq 1 \hat{3}$ \\
\hline & $-27 \leq 1 \leq 27$ & $-13 \leq 1 \leq 13$ \\
\hline Data collected & 26425 & 18172 \\
\hline Unique data $\left(\mathrm{R}_{\text {int }}\right)$ & $11174,(0.0250)$ & $4500,(0.0380)$ \\
\hline Final $R_{1}, w R_{2}$ & $0.0254,0.0620$ & $0.0390,0.0831$ \\
\hline Goodness of tit on $\mathrm{F}^{2}(\mathrm{~S})$ & 1.027 & 1.040 \\
\hline Largest diff peak and hole /e $\AA^{-3}$ & $1.784,-1.163$ & $3.117,-1.065$ \\
\hline
\end{tabular}
tion for complex 2 is seen at $286 \mathrm{~cm}^{-1}{ }^{-17}$ Our experimental

Table 1. Crystallographic and structure refinements data for complexes 1 and 2 interpretations of the individual vibrational bands confirm the results of the previous findings on the infrared spectrum of solid $\mathrm{NaDMP}^{+2}$ and other ab initio contputational calculations such as normal coordinate analy sis of DMP..$^{43}$

The ${ }^{\mathrm{H}} \mathrm{H}$ NMR spectrum of $\mathbf{1}$ exhibited two broad singlets for $\mathrm{CH}_{3}$ and $\mathrm{CH}_{2}(1.51$ and 4.69$)$ protons. The ${ }^{13} \mathrm{C} N \mathrm{NR}$ spectrum of 1 showed two doublets for $\mathrm{CH}_{3}$ and $\mathrm{CH}_{2}(\mathrm{I} 6.2$ and 63.3) in agreement with the suggested structure. The phosphorous groups are homotopic and show a singlet $(40.2)$ in the ${ }^{3]} \mathrm{P}$ NMR spectrum. The ${ }^{1} \mathrm{H}$ NMR spectnum of 2 exhibited one doublet for $\mathrm{CH}_{3} \mathrm{O}(5.69)$ and one singlet for $\mathrm{CH}_{3}(2.88)$ protons. The ${ }^{13} \mathrm{C}$ NMR spectnum of $\mathbf{2}$ showed two singlets for $\mathrm{CH}_{3}$ and $\mathrm{CH}_{3} \mathrm{O}$ (38.9 and 55.7) in agreement with the suggested structure. The phosphorous groups are homotopic and show a singlet $(41.0)$ in the ${ }^{\text {il }}$ P NMR spectrum.

Crystallographic data for $\mathbf{1}$ and $\mathbf{2}$ are given in Table $\mathbf{l}$ and selected bond lengths and angles are presented in Table 2 and

\begin{tabular}{|c|c|c|c|}
\hline $\mathrm{Nd}(1)-\mathrm{O}(24) \div 1$ & $2.3118(18)$ & $O(13)-V d(1)-O(5)$ & $91.94(7)$ \\
\hline $\operatorname{Nd}(1)-O(9)$ & $2.3157(17)$ & $\mathrm{O}(24) \div 1-\mathrm{Nd}(1)-\mathrm{O}(1)$ & $90.25(7)$ \\
\hline $\operatorname{Nd}(1)-O(20) \div 1$ & $2.3342(18)$ & $\mathrm{O}(24) \div 1-\mathrm{Vd}(1)-\mathrm{O}(5)$ & $91.11(7)$ \\
\hline$N d(1)-O(13)$ & $2.3424(18)$ & $O(9)-\mathrm{Nd}(1)-\mathrm{O}(5)$ & $89.91(6)$ \\
\hline$N d(1)-O(5)$ & $2.3486(18)$ & $O(20) \div 1-N d(1)-O(5)$ & $178.58(6)$ \\
\hline$N d(1)-O(1)$ & $2.3564(18)$ & $O(9)-\mathrm{Nd}(1)-O(1)$ & $88.70(6)$ \\
\hline$P(1)-O(1)$ & $1.494(3)$ & $O(26) \div 1-N d(1)-O(1)$ & $93.21(7)$ \\
\hline$P(1)-O(2)$ & $1.496(3)$ & $O(13)-N d(1)-O(1)$ & $178.60(6)$ \\
\hline $\mathrm{P}(1)-\mathrm{O}(4)$ & $1.585(4)$ & $O(5)-N d(1)-O(1)$ & $86.67(7)$ \\
\hline$P(1)-O(3)$ & $1.586(3)$ & $\mathrm{O}(1)-\mathrm{P}(1)-\mathrm{O}(2)$ & $115.28(11)$ \\
\hline $\mathrm{O}(24) \div 1-\mathrm{Nd}(1)-\mathrm{O}(9)$ & $178.50(7)$ & $O(1)-P(1)-O(4)$ & $107.15(11)$ \\
\hline$O(24) \div 1-\mathrm{Nd}(1)-\mathrm{O}(20)+1$ & $87.47(7)$ & $\mathrm{O}(2)-\mathrm{P}(1)-\mathrm{O}(4)$ & $111.27(11)$ \\
\hline$O(24) \div 1-\mathrm{Nd}(1)-\mathrm{O}(13)$ & $89.57(7)$ & $O(1)-P(1)-O(3)$ & $110.45(11)$ \\
\hline$O(9)-\wedge d(1)-O(13)$ & $91.50(6)$ & $\mathrm{O}(2)-\mathrm{P}(1)-\mathrm{O}(3)$ & $109.71(11)$ \\
\hline$O(20) \div 1-\Gamma d(1)-O(13)$ & $88.17(6)$ & $\mathrm{O}(4)-\mathrm{P}(1)-\mathrm{O}(3)$ & $102.16(11)$ \\
\hline
\end{tabular}
3 for 1 and 2 respectively. The structure of 1 consists of a [Nd$\left.(\mu \text {-DEP })_{2}\right]$ fragment and a repetition unit in this one-dimen-

Table 2. Selected bond lengths $/ A$ and angle $/^{\circ}$ of 1

\begin{tabular}{|c|c|c|c|}
\hline $\operatorname{Pr}(1)-O(1)$ & $2.362(3)$ & $O(5)-\operatorname{Pr}(1)-O(9)$ & $91.75(12)$ \\
\hline $\operatorname{Pr}(1)-\mathrm{O}(5)$ & $2.376(3)$ & $O(2)+1-\operatorname{Pr}(1)-O(9)$ & $139.63(11)$ \\
\hline $\operatorname{Pr}(1)-O(2) \div 1$ & $2.378(3)$ & $O(6)+2-\operatorname{Pr}(1)-O(9)$ & $98.12(12)$ \\
\hline $\operatorname{Pr}(1)-O(6) \div 2$ & $2.400(3)$ & $O(1)-\operatorname{Pr}(1)-O(10)$ & $73.70(11)$ \\
\hline $\operatorname{Pr}(1)-O(9)$ & $2.458(3)$ & $O(5)-\operatorname{Pr}(1)-O(10)$ & $114.72(11)$ \\
\hline $\operatorname{Pr}(1)-O(10)$ & $2.6+5(3)$ & $O(2)=1-\operatorname{Pr}(1)-O(10)$ & $142.39(10)$ \\
\hline $\operatorname{Pr}(1)-O(10)=1$ & $2.692(3)$ & $O(9)-\operatorname{Pr}(1)-O(10)$ & $73.30(10)$ \\
\hline $\operatorname{Pr}(1)-O(12)=1$ & $2.757(3)$ & $\mathrm{O}(1)-\operatorname{Pr}(1)-\mathrm{O}(10) \div 1$ & $139.51(11)$ \\
\hline $\operatorname{Pr}(1)-O(11)$ & $2.789(4)$ & $\mathrm{O}(5)-\operatorname{Pr}(1)-\mathrm{O}(10) \div 1$ & $68.85(10)$ \\
\hline $\mathrm{P}(1)-\mathrm{O}(1)$ & $1.494(3)$ & $\mathrm{O}(1)-\operatorname{Pr}(1)-\mathrm{O}(11)$ & $7+30(11)$ \\
\hline $\mathrm{P}(1)-\mathrm{O}(2)$ & $1.496(3)$ & $O(5)-\operatorname{Pr}(1)-O(11)$ & $67.79(11)$ \\
\hline $\mathrm{P}(1)-\mathrm{O}(4)$ & $1.585(4)$ & $O(9)-\operatorname{Pr}(1)-O(11)$ & $71.41(11)$ \\
\hline $\mathrm{P}(1)-\mathrm{O}(3)$ & $1.586(3)$ & $O(10)-\operatorname{Pr}(1)-O(11)$ & $47.04(10)$ \\
\hline $\mathrm{O}(1)-\operatorname{Pr}(1)-\mathrm{O}(5)$ & $87.47(12)$ & $O(1)-P(1)-O(2)$ & $118.31(19)$ \\
\hline $\mathrm{O}(1)-\operatorname{Pr}(1)-\mathrm{O}(2) \div 1$ & $77.13(11)$ & $O(1)-P(1)-O(4)$ & $110.3(2)$ \\
\hline $\mathrm{O}(5)-\mathrm{Pr}(1)-\mathrm{O}(2) \div 1$ & $86.83(12)$ & $O(2)-P(1)-O(4)$ & $105.5(2)$ \\
\hline$O(1)-\operatorname{Pr}(1)-O(6) \div 2$ & $83.97(12)$ & $O(1)-P(1)-O(3)$ & $105.86(19)$ \\
\hline$O(5)-\operatorname{Pr}(1)-O(6) \div 2$ & $170.06(12)$ & $O(2)-P(1)-O(3)$ & $110.60(19)$ \\
\hline$O(1)-\operatorname{Pr}(1)-O(9)$ & $143.16(12)$ & $\mathrm{O}(4) \cdot \mathrm{P}(1)-\mathrm{O}(3)$ & $105.7(2)$ \\
\hline
\end{tabular}

Symmetry cades: $1=\mathrm{x}-1 . \mathrm{y} z$

Table 3. Selected bond lengths $/ \AA$ and angle ${ }^{\circ}$ of 2

Symmetry codes: 
sional polymer. As is clear from an ORTEP view of the compound Fig. l(a). the repeation unit of this linear polymer consists of 6-coordinated neodymium atoms, which are linked together via six O-P-O bridges from phosphate esters

The phosphate groups in $\left[\mathrm{Nd}(\mathrm{ll}-\mathrm{DEP})_{3}\right]_{\mathrm{n}}$ are arranged as an abnormal distorted tetrahedron. The angles of $\mathrm{O}-\mathrm{P}-\mathrm{O}$ and $\mathrm{EtO}-\mathrm{P}-\mathrm{OEt}$ are unequal. The angle of the $\mathrm{EtO}(3)-\mathrm{P}(1)-\mathrm{O}(4) \mathrm{Et}$ moiety is $102.16(11)^{\circ}$. whereas that of $\mathrm{O}(1)-\mathrm{P}(1)-\mathrm{O}(2)$ is $115.28(11)^{\circ}$. According to a survey on similar polymeric [Ce_$\left.(\mu-\mathrm{DEP})_{6}(\mathrm{TEP})\right]_{n}$ complexe, an acceptable reason is simultaneous $z$-in and $z$-out distortions for the DEP. In addition. the conformation of the DEP anion depends on the C-O-P-O angles. In this complex, ${ }^{33}$ we observed the gt (gauche, trans) conformation for the DEP base on the dihedral angles. At this complex. for example the dihedral angles of one of the DEP

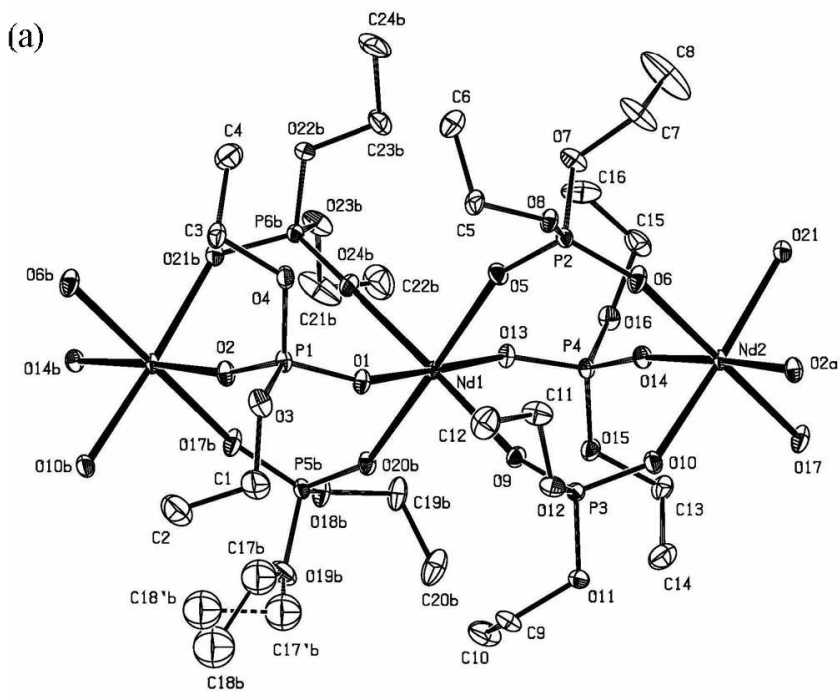

(b)

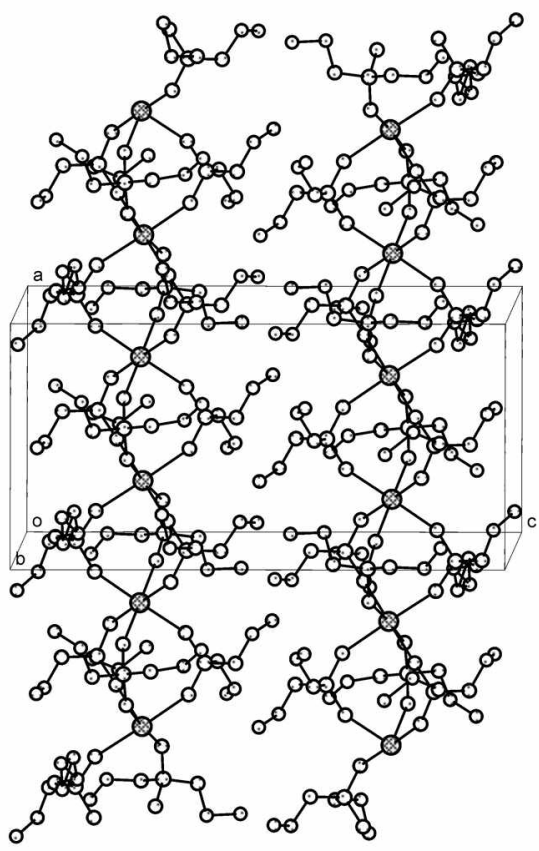

Figure 1. Graphical representation of 1 (40\% probability for the thermal ellipsoids) (a) and the unit cell-packing diagram of 1 (b). Hydrogen atoms are omitted for clarity. ligands are: $\mathrm{C}(1)-\mathrm{O}(3)-\mathrm{P}(1)-\mathrm{O}(4)=-177.4(2)^{\circ}$ and $\mathrm{C}(3)-\mathrm{O}(4)$ $\mathrm{P}(1)-\mathrm{O}(3)=-75.5(2)^{\circ}$. The unit cell packing diagram of the complex 1 is shown in Figure l(b).

The structure of 2 consists of a $\operatorname{Pr}(\mu-\mathrm{DMP})=\left(\mu-\mathrm{NO}_{3}\right)-$ (DMSO)] fragment and a repetition unit in this one-dimensional polymer. An ORTEP plot (Fig. 2(a)) shows that the complex consists of one praseodymium. which is linked to other fragnents via four O-P-O bridges of four phosphate esters: also. one DMSO and two nitrate are linked to each praseodỵmium via its oxỵgen atom during chelating and bridging. There is a 4-membered circle created by the cooperation of two oxygen atoms of nitrate ion (O11.012) and a central $\mathrm{Pr}$ atom. In addition. a third oxygen atom $(\mathrm{O} 10)$ of nitrate also forms a bridge between two neighbor Pr atoms. Figure 2(a) shows the polymeric structure of the title complex, which the (O-P-O) moieties of the phospltate form a double bridge between two praseodymium. The DMSO molecule appears as a monodentate ligand on every single Pr atom.

The phosphate groups. $\left[\operatorname{Pr}(\mu-\mathrm{DMP})_{2}\left(\mu-\mathrm{NO}_{3}\right)(\mathrm{DMSO})\right]_{1 \text {. }}$ are arranged as an abnormal distorted tetrahedron. The angles of $\mathrm{O}(1)-\mathrm{P}(1)-\mathrm{O}(2)$ and $\mathrm{MeO}(3)-\mathrm{P}(1)-\mathrm{O}(4) \mathrm{Me}$ are unequal. The angle of the $\mathrm{MeO}(3)-\mathrm{P}(1)-\mathrm{O}(4) \mathrm{Me}$ moiety is $105.7(2)^{\circ}$. whereas that of $\mathrm{O}(1)-\mathrm{P}(1)-\mathrm{O}(2)$ is $118.31(19)^{\circ}$. According to a survey on similar polymeric La complex ${ }^{30}$ an acceptable reason is simultaneous $z$-in and z-out distortions for the DMP. In addition. the conformation of the DMP anion depends on the C-O-P-O torsion angles. In this complex. we expectedly observed the gg (gauche. gauche) conformation for the DMP base on the dihedral angles. At this complex, for example. the

(a)

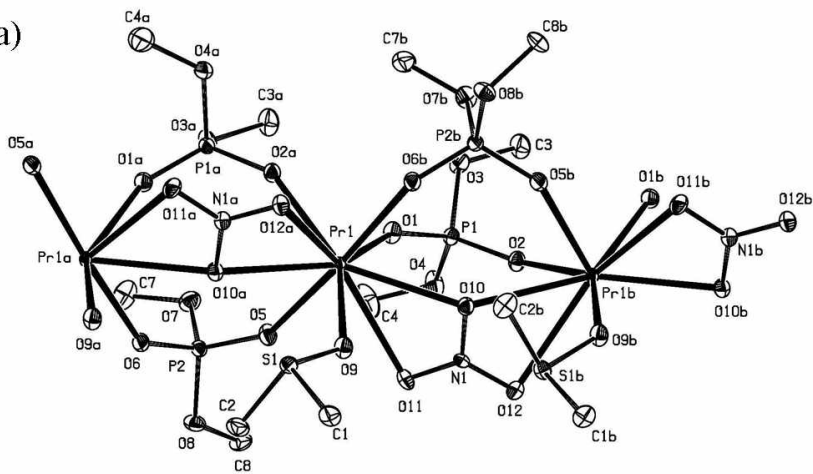

(b)

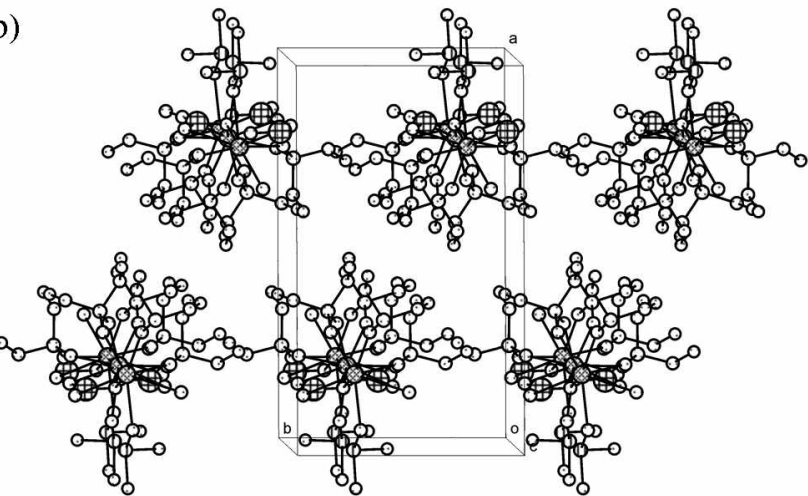

Figure 2. Graphical representation of 2 ( $40 \%$ probability for the thermal ellipsoids) (a) and the unit cell-packing diagram of 2 (b). Hydrogen atoms are omitted for clarity. 
torsion angles of one of the DMP ligands are: $\mathrm{C}(3)-\mathrm{O}(3)$ $\mathrm{P}(1)-\mathrm{O}(4)=-76.0(4)^{\circ}$ and $\mathrm{C}(4)-\mathrm{O}(4)-\mathrm{P}(1)-\mathrm{O}(3)=-95.8(5)^{\circ}$. Each $\mathrm{Pr}$ center occupies an irregular distorted tricapped trigonal prismatic geometry with the DMSO ligand in the vertical position. The angle of $\mathrm{S}(1)-\mathrm{O}(9)-\mathrm{Pr}(\mathrm{l})$ is $128.70(19)^{\circ}$. The large mentioned angle may belong to a steric hindrances induced by the methyl groups of DMSO and lone pairs on the oxygen of DMSO with the Pr atom enviromment. According to experimental geometry data for DMSO the bond angles are $\mathrm{CSC}=96.6^{\circ}$ and $\mathrm{CSO}=106.5^{\circ}$. At this complex the bond angles of the DMSO ligand are: $\mathrm{C}(1)-\mathrm{S}(1)-\mathrm{C}(2): 99.5(2)^{\circ}, \mathrm{O}(9)-\mathrm{S}(1)-\mathrm{C}(1)$ : $105.1(2)^{\circ}$ and $O(9)-S(1)-C(2): 105.3(2)^{\circ}$. Therefore we observed that they have almost not changed. It is clear from Figure 2(a) that. a Pr ion is connected to adjacent Pr by bridging of four DMP and two nitrate ions. These infinite chains are packed along the $b$-axis to create the channels to which $\mathrm{O}-\mathrm{Pr}$ bond of DMSO molecules are perpendicular. The unit cell packing diagram of the complex 2 is shown in Figure 2(b).

Supplementary Materials. CCDC 693501 and 693502 contain the supplementary crystallographic data for $\mathbf{1}$ and $\mathbf{2}$ respectively. These data can be obtained free of charge wa http :u'w ccdc.camacukconts retrieving.homl, or from the Cambridge Crystallographic Data Centre. 12 Union Road. Cambridge CB2 1EZ. UK: fax: (+44) 1223336033 ; or e-mail: depositáccdc.cam.acitk

\section{References}

1. Weis, K.; Valurenkamp, H. Eur. J. Inorg. Chent 1998, 271

2. Trösch, A: Vahrenkamp, H. Inorg. Chent. 2001, t0, 271

3. Jurek, P. E.; Martell, A. E. Inorg. Chem. 1999, 38, 6003.

4. Bazzicalupi, C.; Bencini, A.; Bianchi, A.; Fusi, V.; Giorgi, C.; Paoletti, P.: Valtancoli, B.; Zanchi, D. horg. Chem 1997,36,2784.

5. Jones, D. R.; Lindoy, L. F.; Sargeson, A. M.; Snow, M. R. lhorg. (Chem. 1982, 21,415j

6. Hikichi, S: Tanaka, M:; Moro-oka, Y:; Kitajima, N. J. Chem. Soc. Chem. Commm 1992, 814.

7. Wall, M.: Hynes, R. C.: Chin, T. Angew, Chem, Int Ed. Engl. $1993,32,1633$.

8. Malıroof-Tahir, M.: Karlin, K. D.: Chen, Q: Zubieta, I. Inorg. Chim. Acto 1993, 207, 135.

9. Adams, H.: Bailey, N. A.; Fenton, D. A: He, Q.-Y. J. Chem. Soc., Dalton Trans. 1995, 697

10. Yan, S : Pan, X.; Tavlor, L. F.; Zhang, J. H.; O'Connor, C. J.; Britton, D: Anderson, O. P.: Que, L. Inorg. Chim. Acta 1996, $2+3,1$.

11. Kövari, E: Krämer, R. J. Ant. Chem. Soc. 1996, 118, 12704.

12. Koike, T.; Inole, M.; Kinura, E.; Shiro, M. J. Am. Chen. Soc. 1996, 118,3091

13. He, C: Gomez, V: Spingler, B.: Lippard, S. J. Inorg. Chem. 2000, 39, 4188 .

14. Yamaguchi, K.: Akagi, F.; Fujinami, S.; Suzuki, M.: Shionoya,
M.; Suzuki, S. Chem. Conmmm. 2001, 375

15. Tanase, T.; Watton, S. P.: Lippard, S. I. J.Am. Chem. Soc. 1994, 116,9401 .

16. Albehyl, S.: Averbuch-Pouchot, M. T.; Belle, C.: Krebs, B.; Pierre, J. L.; Saint-Aman, E.; Torelli, S. Eur. J. horg. Chem. 2001,1457

17. Kimura, E.; Aoki, S.: Koike, T.: Shiro, M. J. Am. Chem. Soc. 1997, 119, 3068.

18. Spiccia, L.: Grahan, B.: Hearn, M. T. W.: Lazarev, G.; Moubaraki, B.; Murray, K. S.; Tiekink, E. R. T. J. Chem. Soc., Dalton Trons. 1997,4089

19. Ye, B.-H.: Li, X.-Y.: Xue, F.: Mak, T. C. W. Chem. Commm. 1997, 2407

20. Cargill Thompson, A. M. W.: Bardwell, D. A.: Teffery, J. C.: Ward, M. D. Inorg. Chim. Acto 1998, 267, 239

21. Moubaraki, B.: Murray, K. S.: Ranford, T. D.; Wang, X : Xu, Y. Chem. Commm 1998. 353

22. Paul, R. L: Amoroso, A. T: Jones, P. L; Couchman, S. M: Reeves, Z. R.: Rees. L. H.: Jeffery. J. C.: Mocleverty. I. A.: Ward, M. D. J. Chent. Soc, Dalton Tronts. 1999, 1563

23. Angeloff, A.: Daran, J.-C.: Bemadou, J.; Meunier, B. J. Organomet. Chem, 2001, 624, 58 .

24. Yamami, M; Furutachi, H.; Yokovama, T.; Okawa, H. Inorg. Chem 1998, 37, 6832

25. Aoki, K. J. Chem Soc, Chent Conmm 1977, 600

26. Cini, R.; Marzilli, L. G. Inorg. Chemt. 1988, 27, 1856

27. Weis, K.; Rombach, M.; Valurenkamp, H. Inorg. Chem. 1998. 37,2470 .

28. Müller-Hartmann, A.: Vahrenkamp, H. Em, J. Jhorg. Chem. 2000, 2355.

29. Gross, F.; Müller-Hartmann, A.; Vahrenkamp, H. Eur. J. Ihorg. Chem. 2000, 2363

30. Rafizadeh, M.; Amani, V.; Broushaky, M. Anal. Sci. 2006, 22, S1 13

31. Rafizadeh, M.; Amani, V. Anat Sci. 2006, 22, xll1.

32. Ratizadeh, M: Hoseinzadeh, F; Amani, V. Anal. Sci. 2006, $22, \mathrm{x3}$.

33. Amani, V.: Rafizadeh, M.: Yollsefi, M.: Zargar, N. S. Anal Sci. 2006, 22, $\times 303$.

34. Rafizadeh, M.: Amani, V: Aghayan, H. Acta Cnstallogr. 2006. E62, $\mathrm{m} 2150$

35. Rafizadeh, M.: Tayeher, R.; Amani, V.; Nasseh, M. Bull. Konean Chem. Soc. 2005, 26,594

36. Rafizadeh, M.; Amani, V.; Farajian, H. Z. Anorg. Alleg. Chem. $2007,633,1143$

37. Rafizadeh, M: Amani, V. Acta Cnstallogr: 2006, E62, ml776.

38. Ratizadeh, M.; Amani, V. Z. Anorg. Allg. Chem. 2007, 633, 2738.

39. Sheldrick. G. M. SHELITL v. 5.10, Structure Detenmination Software Suite; Bruker AXS: Madison, Wisconsin, USA, 1998.

40. Nakamato, K. Infrared and Raman Spectra of Inorganic and Coordination Componds. Part B. Applications in Coordination, Organometallic, and Bioinorganic Chemistm, $5^{\text {th }}$ ed.; John Wiley \& Sons: New York, 1997.

41. Balagina, M.; Banishev, F.: Voronko, K.: Osiko, V.; Sobol, A:; Chudinova, N. Iz'. Aliad. Kank SSSR, Neorg Mater. 1985, 21, 712 .

42. Fry, F. H.; Tensen, P.; Kepert, C. M; Spiccia, L. Inorg. Chem. $2003, \$ 2,5637$

43. Floriar1, J.; Baumruk, V; Strajbl, M.; Bednarova, L.; Stepanek, T. J. Phus Chem. 1996. 100, 1559 